\title{
Potential Use of Fly Ash Base-Geopolymer as Aggregate Substitution in Asphalt Concrete Mixtures
}

\author{
I DewaMade Alit Karyawan ${ }^{\# * 1}$, ErvinaAhyudanari ${ }^{\# 2}$, Januarti Jaya Ekaputri ${ }^{\# 3}$ \\ \#Department of Civil Engineering, Faculty of Civil, Environmental, and Earth Engineering, \\ Institut Teknologi SepuluhNopember \\ Kampus ITS Sukolilo, Surabaya 60111, East Java-Indonesia \\ *Departmentof Civil Engineering, Faculty of Engineering, Universitas Mataram \\ Jalan Majapahit 62 Mataram 83125, Nusa Tenggara Barat-Indonesia \\ 1dewa19.66@gmail.com \\ 2ervina@ce.its.ac.id \\ 3 januarti@ce.its.ac.id
}

\begin{abstract}
Infrastructure industry is still dominant in developing countries. These activities requires a large number of aggregates. To make cement concrete and asphalt concrete, itrequires $60 \%$ to $75 \%$ of aggregate in total volume of the mixture. This high volume of aggregates may cause reduction on availability of natural aggregate. Another problem is that not all area in Indonesia has the ability to provide adequate aggregates so that it can support the infrastructure development, especially in remote areas. The aggregate mobilization may face disruption. This research attempts to present an idea of creating an artificial aggregate. The artificial aggregate is made of power plant waste that is mixed with alkali silica, named as fly ash geopolymer. Previous study indicates that the use of fly ash geopolymer as filler replacement in asphalt concrete mixture, is able to double the stability of Marshall test. This experiment serves a role to design an artificial aggregate.
\end{abstract}

Keywords -artificial aggregate, fly ash geopolymer, asphalt mix materials

\section{INTRODUCTION}

Increasing infrastructure development in most parts of the world, especially in developing countries, has resulted in reduced availability of raw materials. The use of natural resources to produce raw materials on an ongoing basis can threaten environmental conditions. Aggregates are one of the raw materials produced from rock exploration in nature. The aggregate is made of stone-crusher installation. The provision of aggregates to meet the natural aggregate needs of the infrastructure industry leads to depletion of natural resources [1][2]. This is understandable considering to make concrete cement and asphalt concrete, it requires $60 \%$ to $75 \%$ of aggregate of the total mixed volume [3]. The need for raw materials in the form of aggregate to support this infrastructure development cannot be fully met in every Indonesia area, especially in remote areas. There can be various obstacles in aggregate mobilization because all of Indonesian areas are not provided by adequate transportation facilities and infrastructures.Thus, it is necessary for sustainable efforts to develop alternative materials such as construction and dismantling waste and industrial waste to be used as replacements of natural aggregates [3]. There have been many studies using waste as artificial aggregates. A research using dismantling of buildings or debris caused by earthquake, for example brick, has been done to find new alternative material in the form of coarse aggregate of waste material. The use of brickle brick can reduce the problem and simultaneously help the conservation of natural resources [1]. There is also an artificial lightweight aggregate production using bottom ash from urban solid waste combustion. This is applied by stabilizing the bottom ash by adding cement, lime as a binder and made of using rotary granulator pan [4]. Another artificial aggregate research is conducted by recycling stone sludge and waste silt. Stone sludge is taken from stone slab processing and waste silt is taken from aggregate wash site. The analyzes include compressive strength, absorption, and artificial aggregate resistance to abrasion under vibration. As a result, water absorption depends on packing density, applied compaction vibration, filling the cavity between the aggregate sludge and the stone waste sludge.The results present denser structure, thus it can reduce the amount of using compacting agent, decrease the water cement ratio, and ultimately increase the compressive strength [5]. Production of light aggregate from fly ash geopolymer has been done by agglomeration technique, including: procurement of row material, composition, mixing, agglomeration to form pellet. In agglomeration process, there is agitation or pressure provision.The agitation manner depends only on the strength of fall with addition of bonding agents such as water glass, kanji solution, and so on. The compaction manner is using a piston suppressor so that it can reduce pores, then it can produce very dense briquettes. Furthermore, the hardening process is by sintering, autoclaving and cold bonding, thenthere will be aggregatedestruction. To form the aggregate, it is sieved to obtain appropriate size of the classification [6].The above description creates an idea to use waste as an artificial 
aggregate material. Waste to be used is fly ash. Fly ash is the result of coal use as a waste from power plants; while there iscurrently less than $50 \%$ of the fly ashutilization. The issue of industrial waste disposal has become an environmental issue, due to pollution caused primarily in big cities where there are limitedlandfills [1][2]. This research is conducted by an idea to make artificial aggregate from fly ash base-geopolymer.

The artificial aggregates are made of fly ash geopolymer paste. This paper discusses the results of a compressive strength test of fly ash geopolymer paste using a cylindrical sample. The resulting compressive strength is compared with other research results. The sample used is cylindrical with $5 \mathrm{~cm}$-diameter and $10 \mathrm{~cm}$ height. Further issue discusses the possibility of the fly ash utilization as an aggregate material based on the results of previous research.

\section{METHOD}

A. Experimental program

The geopolymer paste is made in 3 mixtures design based on $\mathrm{Na}_{2} \mathrm{SiO}_{3}$ ratio with $\mathrm{NaOH}$, namely 1.5, 2.0, and 2.5. The composition of fly ash and alkali is 75\%: 25\%. Each design mixture is used in 6 samples, therefore it requires total of 18 samples. The mixture design can be seen in Table 1 below.

TABLE 1.TheDesign of A Fly Ash Geopolymer Paste Mixture

\begin{tabular}{|c|c|c|c|c|c|}
\hline No. & $\begin{array}{c}\text { Code } \\
\text { Samples }\end{array}$ & Fly ash (\%) & Alkali (\%) & $\begin{array}{c}\text { Molarity } \mathrm{NaOH} \\
(\mathrm{mol} / \text { liter) }\end{array}$ & $\mathrm{Na}_{2} \mathrm{SiO}_{3} / \mathrm{NaOH}$ \\
\hline 1 & $1.5-1$ & 75 & 25 & 8 & 1.5 \\
\hline 2 & $1.5-2$ & 75 & 25 & 8 & 1.5 \\
\hline 3 & $1.5-3$ & 75 & 25 & 8 & 1.5 \\
\hline 4 & $1.5-4$ & 75 & 25 & 8 & 1.5 \\
\hline 5 & $1.5-5$ & 75 & 25 & 8 & 1.5 \\
\hline 6 & $1.5-6$ & 75 & 25 & 8 & 1.5 \\
\hline 7 & $2.0-1$ & 75 & 25 & 8 & 2.0 \\
\hline 8 & $2.0-2$ & 75 & 25 & 8 & 2.0 \\
\hline 9 & $2.0-3$ & 75 & 25 & 8 & 2.0 \\
\hline 10 & $2.0-4$ & 75 & 25 & 8 & 2.0 \\
\hline 11 & $2.0-5$ & 75 & 25 & 8 & 2.0 \\
\hline 12 & $2.0-6$ & 75 & 25 & 8 & 2.5 \\
\hline 13 & $2.5-1$ & 75 & 25 & 8 & 2.5 \\
\hline 14 & $2.5-2$ & 75 & 25 & 8 & 2.5 \\
\hline 15 & $2.5-3$ & 75 & 25 & 8 & 2.5 \\
\hline 16 & $2.5-4$ & 75 & 25 & 8 & 2.5 \\
\hline 17 & $2.5-5$ & 75 & 25 & 8 & 2.5 \\
\hline 18 & $2.5-6$ & 75 & 25 & 8 & \\
\hline
\end{tabular}

\section{B. Materials}

(1) Fly ash

Fly ash used is the remaining coal combustion from Paiton Steam Power Plant unit 5 and 6, Probolinggo Regency, East Java Province. The chemical element content testing is done at PT. Sucofindo Surabaya as shown in Table 2. Visual fly ash can be seen in Fig. 1.Based on their chemical content shown in Table 2, fly ash Paiton is categorized in class $\mathrm{F}$. This indicates by the amount of $\mathrm{Al}_{2} \mathrm{O}_{3}, \mathrm{SiO}_{2}$ and $\mathrm{Fe}_{2} \mathrm{O}_{3}$ content by 74.39\%, greater than 70\% (ASTM C 618-96). According to the results obtained, generally coal is grouped in anthracite or bitumminous coal types. Anthracite or bitumminous coal is a type of coal having high carbon content, low moisture content, and slow speed in combustion. 
TABLE 2.Chemical content of fly ash Paiton power plant

\begin{tabular}{|c|c|c|c|c|c|}
\hline No & Chemical composition & Mass (\%) & No & Chemical composition & Mass (\%) \\
\hline 1 & $\mathrm{SiO}_{2}$ & 36.50 & 10 & $\mathrm{SrO}$ & 0.17 \\
\hline 2 & $\mathrm{CaO}$ & 19.65 & 11 & $\mathrm{CuO}$ & 0.04 \\
\hline 3 & $\mathrm{Fe}_{2} \mathrm{O}_{3}$ & 19.27 & 12 & $\mathrm{ZrO}_{2}$ & 0.03 \\
\hline 4 & $\mathrm{Al}_{2} \mathrm{O}_{3}$ & 19.00 & 13 & $\mathrm{ZnO}$ & 0.02 \\
\hline 5 & $\mathrm{SO}_{3}$ & 3.45 & 14 & $\mathrm{HgO}$ & 0.02 \\
\hline 6 & $\mathrm{~K}_{2} \mathrm{O}$ & 0.90 & 15 & $\mathrm{~V}_{2} \mathrm{O}_{5}$ & 0.02 \\
\hline 7 & $\mathrm{TiO}_{2}$ & 0.71 & 16 & $\mathrm{Rb}_{2} \mathrm{O}$ & 0.01 \\
\hline 8 & $\mathrm{BaO}$ & 0.31 & 17 & $\mathrm{Cr}_{2} \mathrm{O}_{3}$ & 0.01 \\
\hline 9 & $\mathrm{MnO}$ & 0.20 & & Jumlah & 100.00 \\
\hline
\end{tabular}

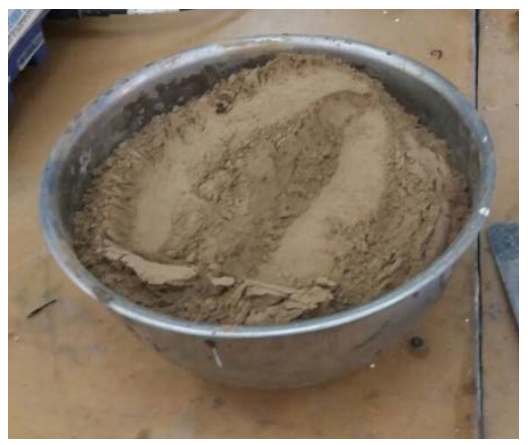

Fig. 1. Fly ash PLTU Paiton units 5 and 6

(2) Alkali Activator

The alkaline activator to the fly ash geopolymer mixture is a mixture of Sodium Hydroxide (NaOH) and Sodium Silicate $\left(\mathrm{Na}_{2} \mathrm{SiO}_{3}\right)$. More detail description of the alkali activator used can be seen as follows:

(a) Sodium Hidroksida $(\mathrm{NaOH})$

It is used Sodium Hydroxide in the form of flake with a purity rate of 98\%. It is also used Sodium Hydroxide in the form of flake as a solution that is dissolved by aquades. The concentration of Sodium Hydroxide used in this study is 8M. Fig. 2 ( $\mathrm{a}$ and b) shows the flake and Sodium Hydroxide $(\mathrm{NaOH})$ solutions.

(b) Sodium Silicate $\left(\mathrm{Na}_{2} \mathrm{SiO}_{3}\right)$

It is used Sodium Silicate in the form of viscous liquid (gel) with ready-made state. The liquid of Sodium Silicate $\left(\mathrm{Na}_{2} \mathrm{SiO}_{3}\right)$ is shown in Fig. 2 (c).

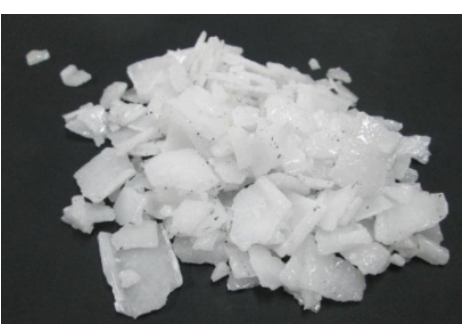

a. $\mathrm{NaOH}$ flakeb. $\mathrm{NaOH}$ solution

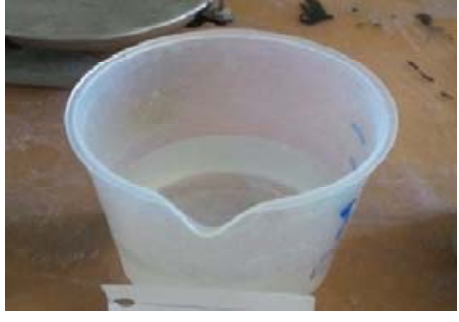

c. $\mathrm{Na}_{2} \mathrm{SiO}_{3}$ solution

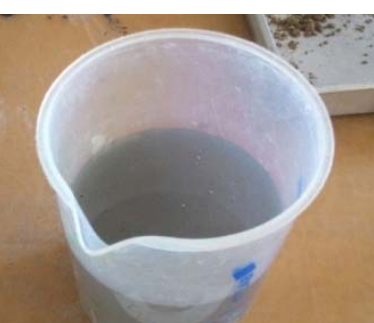

Fig. 2. Alkali activator Sodium Hydroxide and Sodium Silicate

C.Mixing, casting, curing and testing

(1) Preparation of $\mathrm{NaOH}$ solution

Preparation of $\mathrm{NaOH}$ solution is done with molarity of $8 \mathrm{~mol} / \mathrm{l}(8 \mathrm{M})$ solution. The formula used to make a $\mathrm{NaOH}$ solution is:

$\mathrm{n}=\mathrm{V}$ M.

which:

$\mathrm{n}=$ number of solute moles (mole)

$\mathrm{M}=$ molarity of solution (mol / liter)

$\mathrm{V}=$ volume of solution (liter)

Mass $\mathrm{NaOH}=\mathrm{n} \mathrm{Mr}$. 
Which:

$\mathrm{n}=$ number of solute moles (mol)

$\mathrm{Mr} \quad=$ relative atomic mass (gram $/ \mathrm{mol}$ )

The amount of flake $\mathrm{NaOH}$ required to prepare an $8 \mathrm{M} \mathrm{NaOH}$ solution is using the formula (1) as follows:

$\mathrm{n}=\mathrm{V} \mathrm{M}=1$ liter $\times 8 \mathrm{~mol} /$ liter $=8 \mathrm{~mol}$

$\mathrm{Mr} \mathrm{NaOH}=40$,

Which: $\mathrm{Na} \quad=23, \mathrm{O}=16, \mathrm{H}=1$

Mass $\mathrm{NaOH}=\mathrm{n}$ mol Mr

$$
\begin{aligned}
& =8 \mathrm{~mol} \mathrm{x} 40 \text { grams } / \mathrm{mol} \\
& =320 \text { grams }
\end{aligned}
$$

So, to make 1 liter of $8 \mathrm{M} \mathrm{NaOH}$ solution, it requires 320 grams of flakeNaOH. The following weight offlake $\mathrm{NaOH}$ is 320 grams. The flake $\mathrm{NaOH}$ is put into a measuring cup with a capacity of 1000 ml. Then, it adds aquades to the measuring cup filled with $\mathrm{NaOH}$ until the volume is $1000 \mathrm{ml}$. Then it is stirred and waited until it is cool. Once it is cool, the solution is stored in a container and ready for use.

(2) Mixing and casting procedures

Before mixing the fly ash, firstly it is mixing $\mathrm{Na}_{2} \mathrm{SiO}_{3}$ and $\mathrm{NaOH}$ with comparison based on the design.It is necessary to determine the amount of mixture. Then, it is to weigh the fly ash as required in the mixture, namely a gram. If the ratio of fly ash with alkali is $75 \%: 25 \%$, then the amount of alkali is $25 \%$ : (75\% .a) gram.After all of the mixture ingredients are available according to the composition, then the mixing is done.In the mixing process, it is preferable to use mixer to create possible mixture homogeneous. After the mixture is evenly mixed, it is done the casting. Compaction at the time of casting should be perfect so that there are no large pores in the sample. After the mold is fully loaded then it is flattened, then it is clamped with the mold. It is a $20 \mathrm{~mm}$ diameter and $40 \mathrm{~mm}$-heightcylinder mold. After setting, the sample can be removed from the mold.

For example, to make a geopolymer mixture of 200 grams, it requires $75 \%$ of fly ash and $25 \%$ of alkali activator. Where the ratio of $\mathrm{Na}_{2} \mathrm{SiO}_{3}$ with $\mathrm{NaOH}$ in alkali is 2, then it is prepared the materialsas follow:

Fly ash $\quad=75 \% \times 200$ grams $=150$ grams

Alkaline activator $=25 \% \times 200$ grams $=50$ grams,

then:

$\mathrm{NaOH}=1 / 3 \times 50$ grams $=16,67$ grams

$\mathrm{Na}_{2} \mathrm{SiO}_{3} \quad=2 / 3 \times 50$ grams $=33,33$ grams

Mixing process:

Weigh 16,67 gram of $\mathrm{NaOH}$ solution and $\mathrm{Na}_{2} \mathrm{SiO}_{3} 33,33$ grams. Then mix the sodium hydroxide solution and the sodium silicate that has been weighed and stirred until fused. Then weigh fly ash 140 grams. Put the fly ash into the vessel and then pour the alkaline activator. Stir until smooth using a spoon and mixer. Pour the paste into the sample mold while damaging to avoid exposure to the pores in the paste sample. Flatten the surface then clamp. Afterwards, dry the sample mold. The geopolymer sample is stored in a container. Other samples are conducted in the same manner according to the mixturecomposition. Fig. 3 is the process of mixing fly ash geopolymer paste.

a. Treatment (Curing)

Samples removed from the mold are further wrapped with a damp cloth to keep it moist. This is important so there is no crack in the sample. The treatment is performed until the 28-day of tested sample.

b. Testing

Testingof pasta samples is conducted at 28 days. The sample surface of the paste cylinder should be ascertained in a flat state before testing. It is also important to pay attention to the test object flatness because it greatly influenceson the value of compressive strength. Then, weigh the specimen to get its density value. To know the density value, it is the weight of the specimen divided by the cylindrical specimenvolume. The compressive strength test may be performed after the specimen complies with the requirements. 


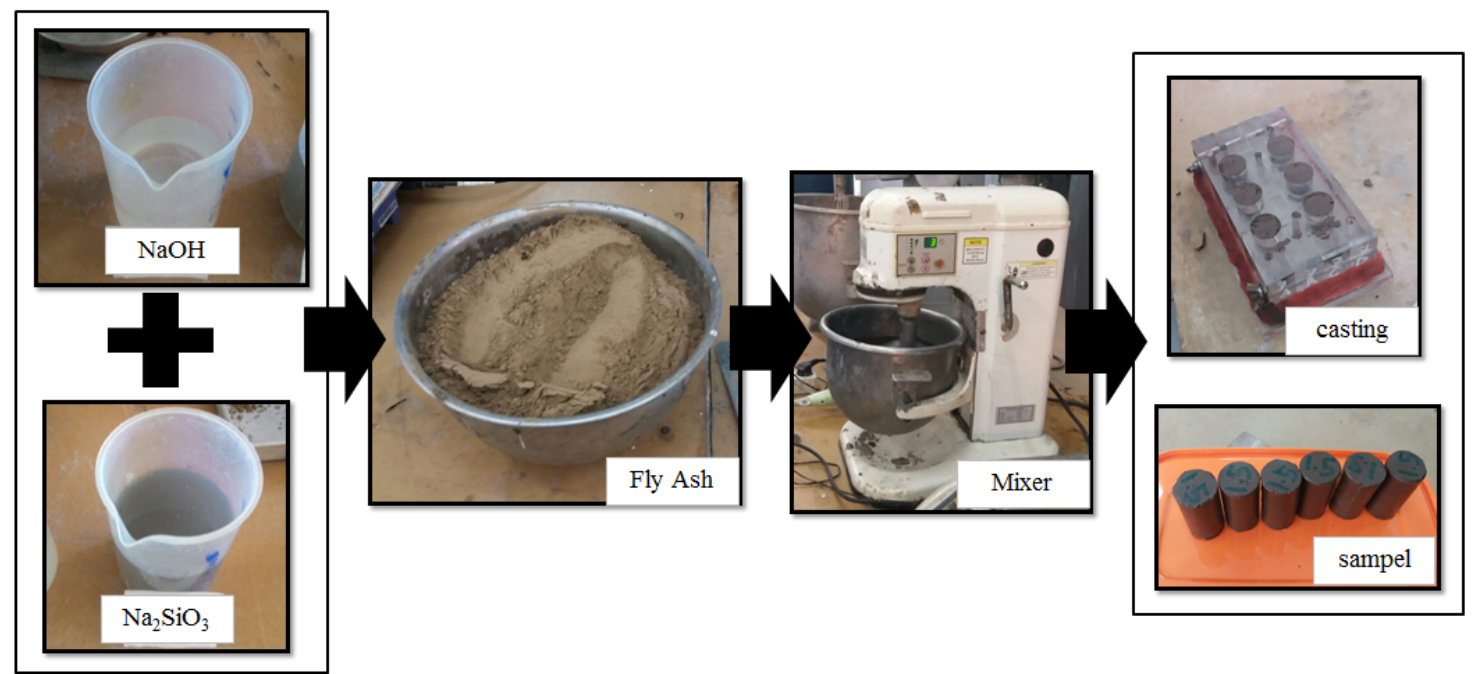

Fig.3. The process of mixing fly ash geopolymer paste

\section{Results and Discussion}

\section{A. Result}

The results of the compressive strength test as well as the complete density of the geopolymer paste samples in various compositions are shown in Table 3 below.

TABLE 3.Test results of fly ash geopolymer samples

\begin{tabular}{|c|c|c|c|c|c|c|c|c|c|}
\hline $\begin{array}{c}\text { Mixed } \\
\text { Number }\end{array}$ & $\begin{array}{l}\text { Code } \\
\text { Sample }\end{array}$ & $\begin{array}{l}\text { Weight } \\
\text { (gr) }\end{array}$ & $\begin{array}{c}\text { Density } \\
\left(\mathrm{gr} / \mathrm{cm}^{3}\right)\end{array}$ & $\begin{array}{c}\text { Compressive } \\
\text { strength } \\
\text { (MPa) }\end{array}$ & $\begin{array}{l}\text { Mixed } \\
\text { Number }\end{array}$ & $\begin{array}{c}\text { Code } \\
\text { Sample }\end{array}$ & $\begin{array}{c}\text { Weight } \\
\text { (gr) }\end{array}$ & $\begin{array}{l}\text { Density } \\
\left(\mathrm{gr} / \mathrm{cm}^{3}\right)\end{array}$ & $\begin{array}{l}\text { Compressive } \\
\text { strength } \\
\text { (MPa) }\end{array}$ \\
\hline 1 & $1.5-1$ & 29,50 & 2,35 & 36,35 & 10 & $2.0-4$ & 29,80 & 2,37 & 25,91 \\
\hline 2 & $1.5-2$ & 29,40 & 2,34 & 23,27 & 11 & $2.0-5$ & 28,90 & 2,30 & 30,01 \\
\hline 3 & $1.5-3$ & 30,10 & 2,39 & 53,33 & 12 & $2.0-6$ & 29,40 & 2,34 & 78,99 \\
\hline 4 & $1.5-4$ & 30,00 & 2,39 & 49,83 & 13 & $2.5-1$ & 28,80 & 2,29 & 19,72 \\
\hline 5 & $1.5-5$ & 29,30 & 2,33 & 78,07 & 14 & $2.5-2$ & 28,80 & 2,29 & 27,73 \\
\hline 6 & $1.5-6$ & 29,10 & 2,31 & 47,71 & 15 & $2.5-3$ & 28,80 & 2,29 & 40,66 \\
\hline 7 & $2.0-1$ & 30,20 & 2,40 & 48,77 & 16 & $2.5-4$ & 29,00 & 2,31 & 27,07 \\
\hline 8 & $2.0-2$ & 31,60 & 2,51 & 36,50 & 17 & $2.5-5$ & 29,30 & 2,33 & 30,47 \\
\hline 9 & $2.0-3$ & 29,50 & 2,35 & 23,93 & 18 & $2.5-6$ & 28,60 & 2,28 & 37,06 \\
\hline
\end{tabular}

Based on Table 3 above, the calculation of average density and compressive strength of the fly ash geopolymer paste is used to determine the inter-variablerelationship. The average density of fly ash geopolymer for the ratios of $\mathrm{Na} 2 \mathrm{SiO} 3$ and $\mathrm{NaOH}$ by 1.5, 2.0 and 2.5 are 2.35, 2.38, and 2.30. While the average compressive strength of fly ash geopolymer paste for the ratios of $\mathrm{Na} 2 \mathrm{SiO} 3$ and $\mathrm{NaOH}$ by 1.5, 2.0 and 2, 5 are 48.09, 40.68 and 30.45. Fig. 4 shows the compressive strength relationship with density. Fig. 5 shows the compressive strength relationship with $\mathrm{Na}_{2} \mathrm{SiO}_{3}$ with $\mathrm{NaOHratios}$.

\section{B. Discussion}

An artificial aggregate of fly ash geopolymer is made of fly ash based on geopolymer paste. Fly ash is a material having characteristics and as a source of aluminosilicate. The geopolymer characteristics of fly ash have been studied extensively in the last decade [7]. A number of fly ash geopolymer with alkali pereactive utilization is done by various methods. The cost-effective method is by using low energy. One of the energysaving methods used in the manufacture of fly ash geopolymer paste is cold bonding method[8]. The findings suggest that the fly ash is suitable for making geopolymers, and the resulting geopolymer indicates the mechanical properties and high durability[7]. This type of alkali activator plays an important role in the geopolymerization process and has a significant influence on the geopolymer mechanical strength. Currently, the most commonly used basic activation is the combination of Sodium Silicate $\left(\mathrm{Na}_{2} \mathrm{SiO}_{3}\right)$ solution and Sodium Hydroxide $(\mathrm{NaOH})$ solution with different $\mathrm{Na}_{2} \mathrm{SiO}_{3}$ and $\mathrm{NaOH}$ mass ratio [9]. 


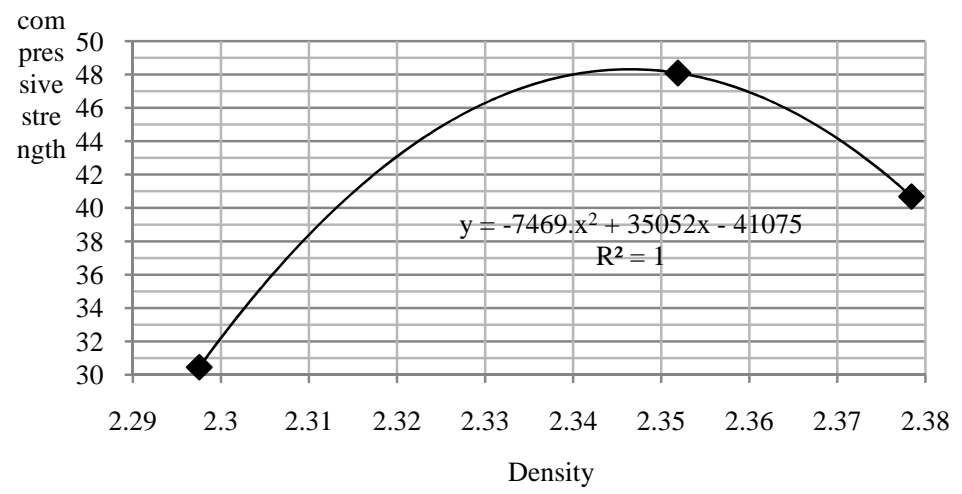

Fig. 4. Relation of compressive strength (y) with density (x)

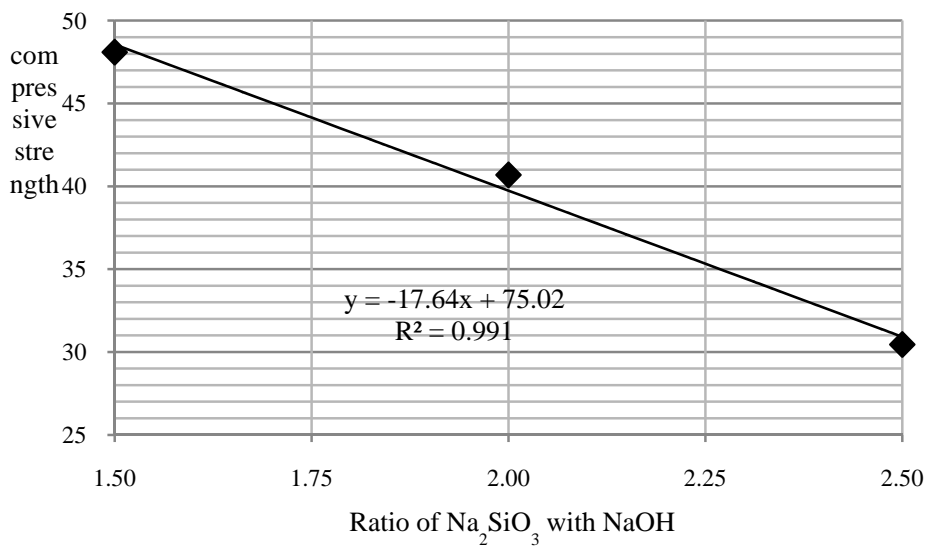

Fig.5. The compressive strength (y) relationship with the alkali activator ratio of $\mathrm{Na}_{2} \mathrm{SiO}_{3}$ with $\mathrm{NaOH}(\mathrm{x})$

Likewise in this study, in Fig. 5 it can be seen that the geopolymer compressive strengh is influenced by the $\mathrm{Na}_{2} \mathrm{SiO}_{3}$ and $\mathrm{NaOH}$ ratios. Lower $\mathrm{Na}_{2} \mathrm{SiO}_{3}$ and $\mathrm{NaOH}$ ratios lead to higher paste compressive strength. The highest average compressive strength of $48.09 \mathrm{MPa}$ can be obtained at ratio of $\mathrm{Na}_{2} \mathrm{SiO}_{3}$ and $\mathrm{NaOH}$ by 1.5. The lowest average compressive strength is $30.45 \mathrm{MPa}$ in $\mathrm{Na}_{2} \mathrm{SiO}_{3}$ and $\mathrm{NaOH}$ ratio of 2.5. According to Shuaibu [10] in addition to the influence of $\mathrm{Na}_{2} \mathrm{SiO}_{3}$ and $\mathrm{NaOH}$ ratios, the optimal strength of geopolymers is also influenced by the molarity of $\mathrm{NaOH}$, fly ash ratio and alkali activator and temperature preservation [9]. The statement is supported by a study which states that the increase in molarity of $\mathrm{NaOH}$ from $8 \mathrm{M}$ to $14 \mathrm{M}$ with the same $2.5 \mathrm{Na}_{2} \mathrm{SiO}_{3}$ and $\mathrm{NaOH}$ ratios increases the compressive strength by $10 \mathrm{MPa}$, from $57 \mathrm{MPa}$ to $67 \mathrm{MPa}$ [10]. With the same molarity of $8 \mathrm{M} \mathrm{NaOH}$ and the variation in the ratio of $\mathrm{Na}_{2} \mathrm{SiO}_{3}$ to $\mathrm{NaOH}, 0.5,1.0,1.5,2.0$, and 2.5, Risdanareni et al. found that there is an increase of the paste compressive strength from a ratio of 0.5 to 2.0, then it is decreased by 2.5. However, there are different results when usingmolarity of $10 \mathrm{MNaOH}$, where the compressive strength increase is based on the increase of $\mathrm{Na}_{2} \mathrm{SiO}_{3}$ to NaOHratios. The highest compressive strength can be achieved in ratio of 2.5 by $30.97 \mathrm{MPa}$ [11]. This means that the geopolymer compressive strength can be increased by modifying the mixture namely by changing $\mathrm{Na}_{2} \mathrm{SiO}_{3}$ to $\mathrm{NaOH}$ ratio as well as the molarity of $\mathrm{NaOH}$. So that, natural aggregate compressive strength of $33.0 \mathrm{MPa}$ [11] can be achieved by fly ash geopolymer paste. Even fly ash geopolymer pastes is greatly possibly to have higher compressive strength.The activator ratio and the concentration of $\mathrm{NaOH}$ solution have an important role to the compressive strength value of the geopolymer paste. Changes in compressive strength are generally linear with changes in $\mathrm{NaOH}$ concentration as well as $\mathrm{Na}_{2} \mathrm{SiO}_{3}$ and $\mathrm{NaOHratios}$ [12]. The compressive strength of fly ash geopolymer can be increased by changing $\mathrm{Na}_{2} \mathrm{SiO}_{3}$ and NaOHratios, resulting in compressive strength up to $103 \mathrm{MPa}$ [13]. However, in the study by Tajunnisa et al. (2016), it was found that the compressive strength was not only influenced by the ratio of $\mathrm{Na}_{2} \mathrm{SiO}_{3}$ to $\mathrm{NaOH}$, but also by the type of fly ash used. This research usedthefly ash taken from Japan and Indonesia. The ratios of $\mathrm{Na}_{2} \mathrm{SiO}_{3}$ to $\mathrm{NaOH}$ used were 1.5, 2.0 and 2.5. For the geopolymer made of Indonesian fly ash, it is obtained the highest compressive strength at a ratio of 1.5, of 57.5 MPa. As for the geopolymer made of Japan fly ash, the highest is $47.7 \mathrm{MPa}$, at a ratio of 2.5. The geopolymer made of Indonesian fly ash has a higher compressive strength than the Japanese fly ash. This is because the chemical content of Indonesianfly ash is rich in $\mathrm{CaO}$ and $\mathrm{Fe}_{2} \mathrm{O}_{3}$. Fly ash with high $\mathrm{CaO}$ levels causes a reciprocal reaction of polymerization and hydration[14]. 
Several studies have been conducted by making the relationship between the compressive strength of the fly ash base-geopolymer paste with the artificial aggregate properties. There is a research of making artificial aggregate from fly ash geopolymer with compressive strength of 22,8 Mpa; it results in aggregate with water absorption value by $<13,01 \%[15]$.Srinivasan et al.[16], found out that the quality of artificial aggregate is lower than the natural one. This research, it is used natural aggregate and the artificial one for concrete mixture. The results indicates that in the age of 28 days, compressive strength of concrete with natural aggregate is 25.86 $\mathrm{N} / \mathrm{mm}^{2}$ meanwhile, those with artificial aggregate is $18.07 \mathrm{~N} / \mathrm{mm}^{2}$ [15]. However, the research studying on the quality of artificial aggregate is continuously performed out.The aggregate properties are: crashing and impact values, abrasion and water absorption. For crushing values, artificial aggregates obtain a value by $31.8 \%$ that is lower than the natural aggregates, but it has $26.4 \%$ higher impact values. The abrasion value is too low so that it is necessary for upgradingto be used as a road material. Another result is the percentage of aggregate water absorption which is 9 times higher than the natural aggregate, but it can be eliminated by various repair methods such as by using sodium silicate and other materials. Other studies result in specific gravity aggregates of 1.7, bulk densities of $1050 \mathrm{~kg} / \mathrm{m}^{3}$, water absorption of $18 \%$, abrasion values $<40 \%$ and aggregate resistance $<12 \%[17]$.

TABLE 4.Properties of artificial aggregates and natural aggregates

\begin{tabular}{|c|l|c|c|c|c|c|c|}
\hline \multirow{2}{*}{ No. } & \multirow{2}{*}{$\begin{array}{l}\text { Aggregate } \\
\text { Properties }\end{array}$} & $\begin{array}{c}\text { Could } \\
\text { bonded } \\
{[15]}\end{array}$ & $\begin{array}{c}\text { Sintered } \\
\text { pellets[17] }\end{array}$ & $\begin{array}{c}\text { Aardelite } \\
\text { Aggregate[17] }\end{array}$ & Pelletizationprocess[18] & $\begin{array}{c}\text { Sintered fly } \\
\text { ash } \\
\text { aggregate[19] }\end{array}$ & $\begin{array}{c}\text { Crushed } \\
\text { aggregates } \\
\text { stone } \\
{[19][17]}\end{array}$ \\
\hline 1 & $\begin{array}{l}\text { Compressive } \\
\text { strength } \\
\text { (MPa) }\end{array}$ & 22.81 & - & - & 13.72 & 26,7 & 33.0 \\
\hline 2 & $\begin{array}{l}\text { Water } \\
\text { absorption } \\
\text { (\%) }\end{array}$ & $<13.01$ & $14 \%-18 \%$ & $18 \%$ & - & $15 \%-16 \%$. & - \\
\hline 3 & $\begin{array}{l}\text { Specific } \\
\text { Gravity }\end{array}$ & - & $1.30-1.60$ & 1.7 & 2,12 & 1,66 & $2.75-2.95$ \\
\hline 4 & Shape & - & Round & Round & Round & - & Angular \\
\hline 5 & $\begin{array}{l}\text { Bulk Density } \\
\text { (kg/m3) }\end{array}$ & - & $750-900$ & 1050 & 942.68 & - & $1450-1750$ \\
\hline 6 & $\begin{array}{l}\text { Particle size } \\
\text { (mm) }\end{array}$ & - & $5-15$ & - & - & $5-40$ \\
and
\end{tabular}

Table 4 shows the comparative properties of artificial aggregates and natural aggregates. Previous research has shown that the artificial aggregate has lower compressive strength than the natural aggregate. Looking at other properties such as water absorption, specific gravity and bulk density, these also show lower values. Thesevalues are linear with the compressive strength value. The results of the study review obtain primarily by reviewing the compressive strength of cylinders, reinforcing the hypothesis that the artificial aggregates with fly ash geopolymer materials can potentially replace natural aggregates. The compressive strength is correlated with other aggregate properties, so that it can obtain aggregates with better properties than the natural aggregate. These results simultaneously show that the artificial aggregates of fly ash geopolymers qualify as asphalt mixtures. This reasoning is supported by higher compressive strength test results than the compressive strength test for aggregates in some studies. Furthermore, compressive strength the geopolymer may be further added by varying the mixture with modification of the ratios of $\mathrm{Na}_{2} \mathrm{SiO}_{3}$ and $\mathrm{NaOH}, \mathrm{NaOH}$ molarity, fly ash ratio and alkaline activator and temperature preservation. This experiment can be improved by designing artificial aggregates. The quality of artificial aggregate of fly ash geopolymer is directly proportional to the compressive strength of the geopolymer paste used. There is a fact that the paste compressive strength can be increased, then it is possible to obtain a good quality of aggregate. Success will be enhanced by using a pelletization process as an effective way to produce artificial light aggregates [20]. The results show that the use of fly ash geopolymer is prospective for using an artificial aggregate material. Because,it can produce the fly ash geopolymer paste formula with high compressive strength. Since the artificial aggregates have properties such as natural aggregates, it can be used as a mixture of asphalt for roads and airports. Previous research has shown that the use of fly ash geopolymer as a filler on concrete asphalt mixture can lead to double increase of the stability of Marshall test [21].

The statement of Aodah, et al, supports the idea of successful use of artificial aggregates from fly ash. Which it is stated that the determinants of asphalt mixture performance are not only based on the properties, but rather by aggregate gradation. In this case, the parameter is the gradient ratio, which correlates with strength 
parameters and mixed performance [22]. On the other hand, workability is one of the important parameters in designingasphalt mixtures [23]. This is more easily achieved with artificial aggregates, because the grain size can be planned to follow the desired gradation. Review of some papers by Vali and S, allows the use of lightweight aggregates as a modern structural element. The utilization of fly ash for artificial aggregates is a form of attention to the diminished natural aggregate resources. This success will reduce the use of natural aggregates, amid improvements in the infrastructure industry [24].

\section{CONCLUSION}

The conclusions of this study based on Results and Discussion are as follows:

1) Fly ash-based geopolymer is potentially used as an artificial aggregate material for as a replacement aggregate in a concrete asphalt mixture.

2) The quality of artificial aggregate can be increased by increasing the compressive strength of the geopolymer paste.

3) The compressive strength of the fly ash base-geopolymer paste can be increased by modifying the alkali activator, ie the ratio of $\mathrm{Na}_{2} \mathrm{SiO}_{3}$ to $\mathrm{NaOH}$, and the molarity of $\mathrm{NaOH}$.

4) Higher compressive strength leads to better result of artificial aggregate properties, therefore, it is necessary for well plan of the fly ash based-geopolymer paste mixture.

5) The successful utilization of aggregate made from fly ash based-geopolymer, will reduce the use of natural aggregate, so that it can be considered as a form of attention to the depletion of natural resources.

\section{ACKNOWLEDGEMENT}

The authors would like tothank to BUDI DN - LPDP scholarship for their support through Indonesian education scholarship program.

\section{REFERENCES}

[1] F. Debieb and S. Kenai, “The use of coarse and fine crushed bricks as aggregate in concrete,” Constr. Build. Mater., 2008.

[2] P. Priyadharshini, G. S. Mohanganeshanda, and Santhi, “AReviewonArtificialAggregates,” Int. J. Earth Sci. Eng., vol. 5, no. 301, pp. 540-546, 2012.

[3] P. B. Cachim, “Mechanical properties of brick aggregate concrete,” Constr. Build. Mater., 2009.

[4] R. Cioffi, F. Colangelo, F. Montagnaro, and L. Santoro, "Manufacture of artificial aggregate using MSWI bottom ash,” Waste Manag., pp. 281-288, 2011.

[5] F. C. Chang, M. Y. Lee, S. L. Lo, and J. D. Lin, “Artificial aggregate made from waste stone sludge and waste silt,” J. Environ. Manage., 2010.

[6] J. Thomas, “Concrete made using cold bonded artificial aggregate,” Am. J. Eng. Res., no. 1, pp. $2320-847,2013$.

[7] S. Pu, P. Duan, C. Yan, and D. Ren, "Influence of sepiolite addition on mechanical strength and microstructure of fly ashmetakaolingeopolymer paste,” Adv. Powder Technol., 2016.

[8] J. M. J. M. Bijen, “Manufacturing processes of artificial lightweight aggregates from fly ash,” Int. J. Cem. Compos. Light. Concr., 1986.

[9] A. M. M. Al Bakri, H. Kamarudin, M. Bnhussain, I. K. Nizar, A. R. Rafiza, and Y. Zarina, "The Processing , Characterization , and Properties of Fly Ash Based Geopolymer Concrete,” pp. 90-97, 2012.

[10] R. A. Shuaibu, “Compressive Strength of Low Calcium Fly Ash Geopolymer Concrete- A Review,” Int. J. Emerg. Technol. Adv. Eng., vol. 4, no. 4, pp. 463-470, 2014.

[11] P. Risdanareni, J. J. Ekaputri, and M. M. A. B. Abdullah, "Effect of Alkaline Activator Ratio to Mechanical Properties of Geopolymer Concrete with Trass as Filler,” Appl. Mech. Mater., vol. 754-755, no. April, pp. 406-412, 2015.

[12] P. Risdanareni and J. J. Ekaputri, "The Influence of Alkali Activator Concentration to Mechanical Properties of Geopolymer Concrete with Trass as a Filler,” Mater. Sci. Forum, vol. 803, pp. 125-134, 2015.

[13] M. Z. N. Khan, F. uddin A. Shaikh, Y. Hao, and H. Hao, "Synthesis of high strength ambient cured geopolymer composite by using low calcium fly ash,” Constr. Build. Mater., 2016.

[14] Y. Tajunnisa, M. Sugimoto, T. Sato, J. J. Ekaputri, and M. Shigeishi, "Characterization of Low Calcium Fly Ash for Geopolymer Paste,” in 16th International Conference and Exhibition on Structural Faults and Repair, 2016.

[15] G. Perumal and S. Anandan, “Performance evaluation of alkali activated fly ash lightweight aggregates,” Eng. J., vol. 18, no. 1, pp. 77-85, 2014

[16] K. Srinivasan et al., “An Experimental Study on Manufacture of Artificial Aggregates Incorporating Flyash, Rice Husk Ash and Iron Ore Dust,” Int. J. Sci. Eng. Technol. Res., vol. 5, no. 1, 2016.

[17] G. B. Singh, “Artificial Aggregate Production from Fly Ash,” Masterbuilder Bur., 2016.

[18] P. Gomathi and A. Sivakumar, "Characterization on the strength properties of pelletized fly ash aggregate,” ARPN J. Eng. Appl. Sci., vol. 7, no. 11, pp. 1523-1532, 2012

[19] A. R. Rafiza, A. M. M. Al Bakri, H. Kamarudin, I. K. Nizar, D. Hardjito, and Y. Zarina, "Reviews on the Properties of Aggregates made with or without Geopolymerisation Method,” vol. 626, pp. 892-895, 2013.

[20] K. S. Vali and A. Rahim, “Mechanical Properties of Light Weight Engineered Cementitious Composites,” Int. J. Eng. Technol., vol. 8, no. 6, pp. 2937-2945, 2017.

[21] E. Ahyudanari, J. J. Ekaputri, and M. Tardas, “Analysis of Coal Waste Solidification as an Alternative Filler Material in Asphalt Concrete Mixture,” Mater. Sci. Forum, vol. 841, no. November 2015, pp. 65-71, 2016.

[22] H. H. Aodah, Y. N. A.Kareem, and S. Chandra, "Performance of Bituminous Mixes with Different Aggregate Gradations and Binders,” Int. J. Eng. Technol., vol. 2, no. 11, pp. 1802-1812, 2012.

[23] A. Setiawan, L. B. Suparma, and A. T. Mulyono, “The Effect of Aggregate Gradation on Workability of Asphalt Concrete(CFD),” Int. J. Eng. Technol., vol. 8, no. 4, pp. 1750-1757, 2016.

[24] K. S. Vali and B. M. S, “Overview of Artificial Aggregates Overview of Artificial Lightweight Aggregates-A Review,” Int. J. Civ. Eng. Technol., vol. 8, no. 6, 2017. 


\section{AUTHOR PROFILE}

I Dewa Made Alit Karyawan is an Doctoral student at Institut Teknologi Sepuluh Nopember, Indonesia and Associate Professor at Universitas Mataram, Indonesia. He obtained his Master degree in Magister of Civil Engineering from Universitas Brawijaya, Indonesia in 2001. His research interests is in road and airfield pavement.

Ervina Ahyudanari is an Associate Professor at the Institut Teknologi Sepuluh Nopember, Indonesia. She obtained her Ph.D. in Civil Engineering from Universiti Teknologi Petronas, Malaysia in 2014. She obtained her Master of Engineering degree in Civil Engineering at the University of New South Wales in 2003. Her research Interestsis in transportantion, road and airfield pavement.

Januarti Jaya Ekaputri is an Associate Professor at the Institut Teknologi Sepuluh Nopember, Indonesia. She obtained her Ph.D. in Concrete Technologi from The University of Tokyo in Japan in 2010. She obtained her Magister of Structural Engineering degree in Civil Engineering at Institut Teknologi Bandung, Indonesia in 2000. Her research Interests is in concrete and material. 